\title{
PERBANKAN SYARIAH BAGI PERTUMBUHAN DAN PEMBANGUNAN EKONOMI NASIONAL
}

\author{
NADIA FUTRI HARYANI NURODIN \\ SYA. 155024 \\ EKONOMI SYARIAH \\ SEKOLAH TINGGI AGAMA ISLAM NEGERI (STAIN) \\ SORONG \\ E-MAIL : hfaidan7777@gmail.com
}

\section{PENDAHULUAN}

Pada masa krisis ekonomi pada tahun 1998 bank berbasis syariah bisa membuktikan kekuatannya dalam menghadapi krisis berkepanjangan. Namun, perkembangan perbankan syariah belum bisa berkembang pesat di Indonesia. Karena masih ada saja anggapan bahwa Islam dengan sistem nilai dan tatanan normatifnya penghambat laju pertumbuhan ekonomi. Padahal jika dipahami secara utuh, sadar atau tidak sistem ekonomi akan tumbuh dan berkembang dengan baik bila landasannya bertumpu pada nilai dan prinsip syariah.

Tujuan pembangunan nasional yaitu untuk mencapai terciptanya masyarakat yang adil dan makmur. Bank sebagai lembaga intermediasi dalam pengelolaan dana, mempunyai posisi strategis dalam mendorong pertumbuhan dan pembangunan ekonomi nasional. Dalam hal ini diperlukannya juga kerja sama antar masyarakat dengan 
masyarakat pemerintah maupun antara lembaga keuangan dalam memajukan pertumbuhan dan pembangunan perekonomian nasional.

Perbankan syariah dan industri keuangan adalah salah satu pilihan kebijakan yang sangat relevan untuk mendorong pertumbuhan dan pembangunan ekonomi serta sektor riil di Indonesia. Oleh sebab itu, sudah saatnya pemerintah dan rakyat Indonesia untuk membuka mata dan merubah cara pandang terhadap bank syariah sebagai alternatif untuk ditumbuh kembangkan dalam dunia perbankan Indonesia saat ini.

\section{PERBANKAN SYARIAH DAN KONTRIBUSINYA}

Pada tahun 2014 Indonesia menduduki urutan ketujuh sebagai Negara yang memiliki potensi dan kondusif dalam pengembangan industri keuangan syariah. Posisi ini turun tiga peringkat yang sebelumnya pada tahun 2011 Indonesia menempati urutan keempat. Sebagai Negara dengan penduduk muslim terbesar, sudah selayaknya Indonesia menjadi pelopor dan kiblat pengembangam keuangan syariah di dunia. Tapi sangat disayangkan, sebab perkembangan perbankan syariah di Indonesia masih belum menunjukkan perkembangan yang signifikan dari tahuntahun sebelumnya.

Untuk itu, industri perbankan syariah dituntut 
melakukan pengembangan, kreatifitas dan inovasi-inovasi produk baru. Inovasi produk harus menjadi strategi prioritas bagi bank-bank syariah, karena inovasi memiliki peran penting dalam merambah dan menguasai pasar yang selalu berubah. Untuk itu, inovasi produk perbankan syariah harus dirancang instrumennya dan sesuai standar internasional, tetapi harus merujuk pada rumusan strategi pengembangan pasar domestik di Indonesia.

Tidak hanya itu, peranan perbankan syariah juga sudah selayaknya ditingkatkan pada sektor primer yang menjadi tulang punggung ekonomi terutama pada model akad yang lebih menonjolkan prinsip syariah terutama prinsip bagi hasil.

\section{PENUTUP}

Secara tidak langsung perbankan syariah telah memberikan kontribusi penting bagi pertumbuhan dan pembangunan perekonomian nasional dengan melaksanakan fungsi intermediasi keuangan dan menjaga stabilitas keuangan nasional. Perbankan syariah telah menunjukkan kinerja keuangan yang menggembirakan meskipun perannya masih pelu untuk terus dikembangkan lagi. 
Anshori, Abdul Ghofur, 2009, Perbankan Syariah Indonesia, Yogyakarta: Gadjah Mada University Press.

Andriansyah, Yuli, Kinerja Keuangan Perbankan Syariah di Indonesia dan Kontribusinya bagi Pembangunan Nasional. Jurnal Ekonomi Islam, Vol. III, No. 2, Desember 2009.

Bank Indonesia, 2002, Cetak Biru Pengembangan Perbankan Syariah Indonesia, Jakarta: Direktorat Perbankan Syariah Bank Indonesia.

Lewis, Mervyn K dan Lativa M. Algaoud, 2007, Perbankan Syariah: Prinsip, Praktik dan Prospek, Jakarta: PT. Serambi Ilmu Semesta.

Marthon, Said Sa'ad, 2004, Ekonomi Islam di Tengah Krisis Global, Jakarta: Zikrul Hakim.

Siregar Mulya, "Agenda Pengembangan Perbankan Syariah Untuk Mendukung Sistem Ekonomi yang Sehat di Indonesia: Evaluasi, Prospek dan Arah Kebijakan", Iqtisad: Jurnal Ekonomi Islam, Vol. 3, No. 1, Maret 2002. Sjahdeini, Sutan Remy, 2010, Perbankan Syariah, Jakarta: Jayakarta Agung Offset.

Sukardi, Budi, Kepatuhan syariah (SHARIAH COMPLIANCE) dan Inovasi Produk Bank Syariah di Indonesia.

Syukron, Ali, Dinamika Perkembangan Perbankan Syariah di Indonesia. Jurnal Ekonomi dan Hukum Islam, Vol. 3, No. 2, Februari 2013.

Wibowo, Muh. Ghafur, 2007, Potret Perbankan Syariah Terkini: 
Kajian Kritis Perkembangan Perbankan Syariah Terkini, Yogyakarta: Biruni Press. 